\title{
Operational Improvement On Data Validation And Verification Of Health Insurance Assistance Beneficiaries In Indonesia: An Overview Of Accountability/Governance Perspective
}

\author{
Herlan (masrio_herlan@yahoo.com) \\ Jurusan Ilmu Kesejahteraan Sosial FISIP Universitas Indonesia
}

\author{
Bambang Shergi Laksmono (bshergi@ yahoo.com) \\ Jurusan Ilmu Kesejahteraan Sosial FISIP Universitas Indonesia
}

Hartini Retnaningsih (hartiniretnaning@yahoo.com)

Pusat Penelitian, Badan Keahlian DPR RI

\begin{abstract}
Decent data management is a fundamental element in implementing government policies, especially in providing social assistance to the poor. Distribution of social assistance can only be done with the support of proper data management system that runs the data collection process, updating, validating according to the real condition, hence the distribution of social assistance is right on target. This study examines issues which concern on institutional, derivative function and authority in the distribution of social assistance, especially health insurance assistance for the poor and the needy in Indonesia. This study aims to review the whole implementation process of verification and validation on the distribution of health insurance beneficiaries (PBI-JK), starts from its procedures until it is implemented in the locations of MuBa Regency and Palembang City. To achieve the desired objective, this study uses a qualitative method by collecting data from documents, interviews and field observations. As the result, it appears that prelist data services for verification and validation purposes are carried out centrally at the Social Welfare Data and Information Center, Ministry of Social Affairs (PUSDATIN, KESSOS), and for verification and validation in the field are handled by other third parties but only for urban areas.
\end{abstract}

Keywords:

Social Data, Social Beneficiaries, verification and validation, health insurance, accountability

Article Received: 18 October 2020, Revised: 3 November 2020, Accepted: 24 December 2020

\section{Introduction}

Data accuracy of contribution assistance recipients is one of the important issues in the implementation of state contribution assistance for the poor and the needy. If there is a problem with the data used, it will have an impact by not achieving the objectives of the program. The importance of database accuracy and validation in the administration of social assistance is also recognized by the government. Therefore the Ministry of Social Affairs as the party in charge in data collection, updating, verification and validation in the field must regularly updates the data of Health Insurance Beneficiaries (PBI-JK).

In the implementation of data collection and updating, determined mechanism, verification and validation in the field can be seen as a whole process which cannot be separated. A good procedure (mechanism) is when the specified procedure is easy to understand, clear, can be carried out and accounted for. Likewise in its implementation, transparency and participation and accountability become important components in the distribution of social assistance, thus the 
objectives of the program can be achieved and on target.

Similar studies have also been conducted regarding the implementation of updating health insurance data for the poor, including Muhtar (2015) who highlights the verification and validation mechanism of health insurance data for the poor from the perspective of social protection policies implementation in Jambi Regency. The result shows that health insurance has not been maximally utilized because field verification and validation has not been carried out. Other studies such as Maulana (2019) who focuses on examining the implementation of the PBI-JK data verification and validation policy in Ambulu District, Jember Regency. In his research, the implementation of policy was not carried out optimally, this was due to several reasons such as the delivery of unclear information, limited number of human resources, equipment and budgets constraints, misuse of authority, as well as differences in the determination of beneficiary criteria (include weak coordination between sectors). Moreover, Hepat and Rachman (2018) examine the inhibiting factors of PBI-JK data collection in North Heledululaa subdistrict of Gorontalo Regency, which revealed that the inhibitors of PBI-JK data collection were the low level of data collection officers' knowledge, and the implementation of verification and validation in the field that were not optimal.

From these various studies, it can be concluded that there were no a comprehensive determination regarding process of verification and validation of PBI-JK data, start from data collection mechanism to the implementation of verification and validation in the field, especially from the perspective of accountability. Muhtar (2015) only observes the mechanism for updating the health insurance distribution from the perspective of policy implementation, but not the whole process, such as its implementation. The same thing was done by Maulana (2019) who only focuses on studying how the PBI-JK data verification and validation policy implemented while Hepat and Rachman (2018) only identify the obstacles in the field data collection. Even though verification and validation are a unified processes start from the determination of data collection procedures to the implementation in the field which requires a good management system, involve a lot of resources (i.e. data management staff, field staff, operators, beneficiaries, regional officials and so on), and require supporting resources such as operational budget, infrastructure and so on. Therefore verification and validation are carrying out properly, valid and actual.

This study examines the overall verification and validation of PBI-JK data, start from the determined procedures to the implementation in the field from the accountability perspective. This study uses case studies in Musi Banyuasin Regency (Next will be written with Muba Regency) and Palembang City. The selection of Muba Regency as the research area because this district is a pioneer of free healthcare provider in Indonesia (since 2002), and has been awarded by the Universal Health Coverage (UHC) in 2019. While the selection of Palembang City because this city is the capital city of South Sumatra Province with consideration of urban characteristics to be compared with Muba Regency with rural characteristics. The results of this study are expected to contribute the quality improvement of social assistance implementation, particularly in providing health insurance contribution assistance for the poor.

\section{Conceptual Framework}

In the social assistance policy, generally contains several main components related to the allocation of social assistance, such as target beneficiaries, types of social assistance, from financing to responsibility to provide social assistance. This was stated by Gilbert and Terrel (2013) in the social welfare policy as follow: what are the bases of social allocations (universalism or selective); what are the type of social provisions to be allocated (case, in-kind or alternatives), what are the strategies for the delivery of these provisions (privatization or commercialization), 
what are the ways to finance these provisions (taxes, voluntary giving or taxes). This means that in the policy of social assistance distribution, target beneficiaries of social assistance must be cleared and firmed, not to mention the criteria; whether the beneficiary is for all (universal), or only for certain groups (residual). If it is universal, social assistance is provided to everyone without exception. Meanwhile, if the social assistance is provided selectively, it requires procedure or mechanism for data collection and updating the targeted beneficiaries include its organizers and funding (separated from the budget for social assistance programs).

After the procedure or mechanism in the health insurance distribution program becomes clear and obvious, the following step is the implementation of the policy. At this stage everything must be done transparently thus the field staffs can understand their functions and duties. Moreover, public has access to monitor and follow the progress. Information disclosures and transparency are expected to increase public participation in government policies.

With the participation of stakeholders (internally and externally) in organizing the distribution of social assistance, it is expected to be able to empower resources as well as to participate in overseeing the implementation of social assistance distribution.

The importance of information disclosure, transparency and public participation in the provision of social assistance asserted by Bjuremalm, Gibaja and Molleda (2014) on the use of principles of accountability, transparency and participation will make governance of social assistance promotes better performance. This argument also in line with Agere (2000) who states that the implementation of those principles increase responses to public complaint and eventually creates transparency in government system.

The implementation of good governance correlates between the state and the citizens. Accountability, transparency, participation, and rule of law are the basic principles inherent in making and implementing social policies. This is evidenced by the existence of mechanism, rule, organization, public participation, and information disclosure in social policy. Thus it is reasonable when Daly (2003) states that governance is one of the "founding interests" in the discipline of social policy.

Among the various good governance principles that exist today, in general there are numbers of principle in the implementation of governance namely accountability, transparency, participation and rule of law and these principles are endorsed by international organizations and academia (Doeveren, 2011). Similarly stated by Gisselquist (2012), there are at least seven main components in good governance, namely democracy and representation, human rights, rule of law, effective and efficient, transparency and accountability, developmental objectives, and various programs related to the politics and economy.

Accordingly, the principles of good governance which are associated with the implementation of social assistance in general consists of accountability, transparency, and participation. Accountability principle can be interpreted as responsibility to both vertically (structurally) and horizontally (other public). Ahmad (2008) argues accountability as a proactive process of the government in delivering plans, actions and behaviors that have been implemented to the public; Meanwhile, the principle of transparency is defined as disclosure of information and procedures to the public (Doeveren, 2011; Johnston, 2002; Agere, 2000). One of the objectives in this transparency is to encourage the public to participate in making and implementing social policies. Another principle namely participation is interpreted as distribution (delegation) of authority from central government to the regions (decentralization). Participation also can be interpreted as community involvement in the process of making and implementing social policies. 


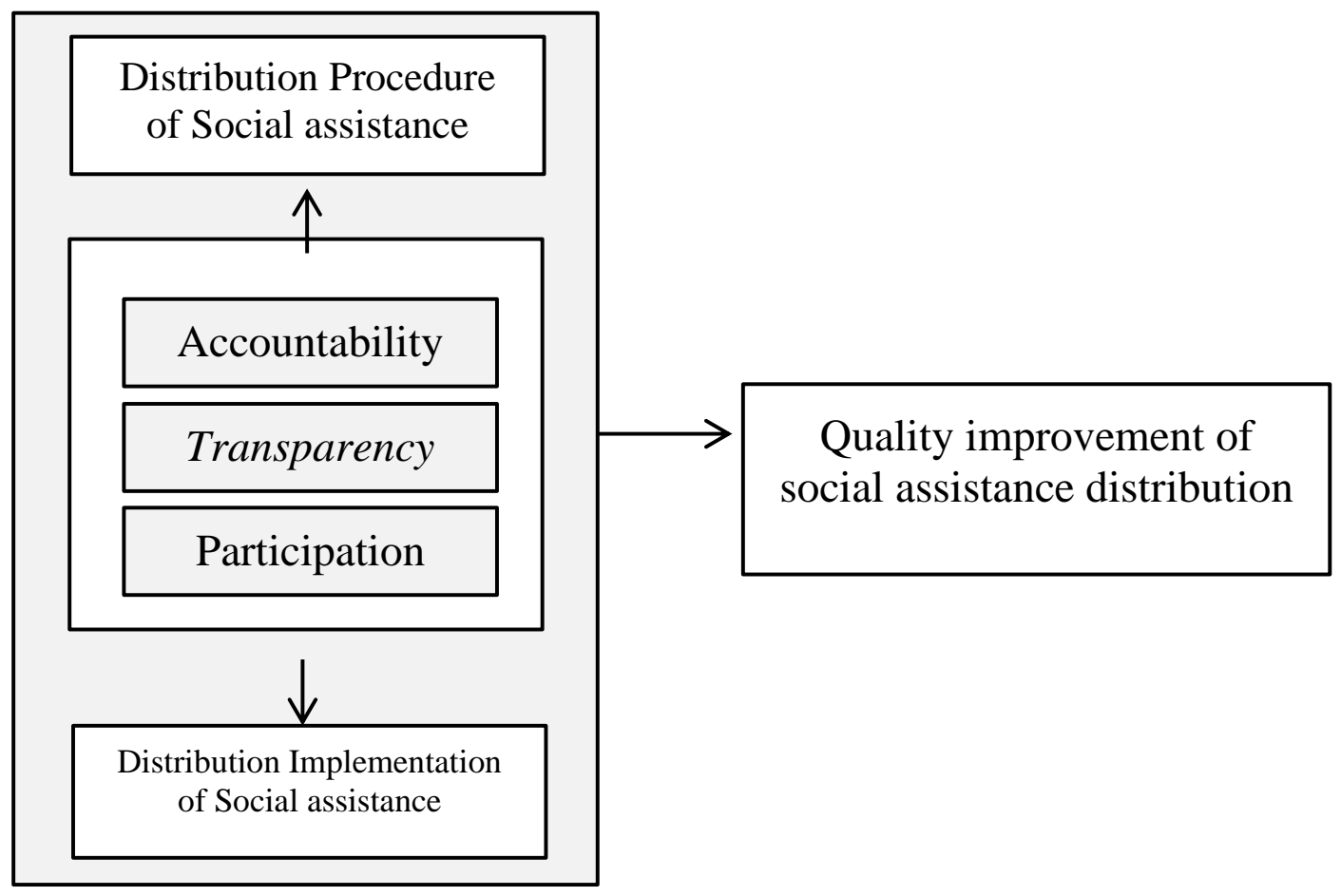

Figure 1. Conceptual Framework

\section{Research methodology}

This research is aimed to understand the entire updating process, especially in terms of verification and validation perspectives of stakeholder management policy; then, every step of the research comes from the subjective assumptions (literature review), next going on to the field condition (validation and verification process), and believed that the accuracy of the verification and validation affects peoples prosperity. Based on Creswell (2016); Rubin and Babbie (2008) this research used the constructivism paradigm (interpretivism) trying to discover the world and develop the subjective meaning of current experiences. Therefore the qualitative approach is used in which the researcher explored and interpreted some information and data from the documents of the study, in-depth interview and observation, then, described the details descriptively, the validation and verification of the field process.
There were two sections in collecting the data; first collecting the information and data to find out the validation and verification of PBI-JK data, it was done through documentation study and interviewed the officer of Information and Data Centre of the Social Ministry (Pusdatin); work section of Social Ministry that responsible in processing, servicing and saving DTKS. Second, based on the process of validation and verification in Muba Regency and Palembang City. Choosing Muba Regency for the research it is because of the Muba regency as the first model of free health service in Indonesia and got Universal Health Coverage (UHC) categorize. While choosing Palembang city it is because of Palembang as the capital of South Sumatera Province which is has the city characteristics, instead of Muba regency with most of the area is the village. The data were collected through documentation study, the observation was done at Muba Social Service office, Palembang Social Service and interviewed 
with the officer of Social Service Muba Regency, Palembang Social Service officer, The officer of TKSK and local officials.

To decide the informer. The researcher begins by deciding the criteria of the informer, to develop the quality of the research, the researcher used the triangulation data sources (documentation study, observation, and interview) retrial of the informer; questioning and review with a partner (fellow researcher); proper references and detailed review (thick description); analyzing and data collecting repeatedly (re-confirm was done through the interview, observation and documentation study.

4. The official of the organizer health contribution assistance

The implementation of $\mathrm{JKN}$ in 2004 as the result of the people's contributive council and government within 10 years of the laws of the National Social Secure System verified (SJSN) 2004. At the first of the JKN implementation, the PBI-JK data that used was from the result of Social and Secure Data Program (PPPS) in 2011 with total 76.4 million people, then 10 million people become 86.4 million people

Based on the National Team for the Acceleration of Poverty Reduction data (2015) the stage of PBI-JK data verification in 2014 started with data validation, verification, and registration by community health insurance participants of Askes Company, then submit the data to Health Ministry (Kemenkes); submit the data to TNP2K to be delivered to Social Ministry and verified PBIJK by Social Ministry.
Then after the total verification of PBI-JK in 2014, there was the improvement of the national total quota 96.4 million people, and 2019 became 96.8 million people. This improvement can be separated from Government commitment to accelerate the JKN program that covers the entire citizens (universe) or universal health coverage, especially reach the poor family.

The result of PBI-JK Social Ministry data verification filled to DTKS system (Basis Data Terpadu/BDT named before) to be processed, saved, and to be verified and validated and to be updated regularly. In the process of PBI-JK data validation and verification, Social Ministry started by taking the first data (prelist); the data were taken by using an online system (using SIKS-NG application), and offline (using a master application), or siksroid (using android handphone); then pre list data were verified and validated through village discussion (musdes) or local village discussion (muskel), and visitation to the PBI-JK household recipients. This result of validation and verification data were input to SIKSNG application (Social Prosperity Information System - Next Generation) by Social Ministry officer (operator), and reported to the next stage gradually. Then, the result of the report cleaned (data cleansing) and be ranked based on the level of the poorness by Kessos Pusdatin before verified by Social Ministry. If in the verification and validation process there were still poor family who have not been recorded, then they can report to the local village office to be listed and get conveyer letter to be given to the Social Ministry, then the Social Ministry officer will list and validate and verify that report. 


\section{Figure 2. Verification Procedure and Data Validation of PBI-JK}

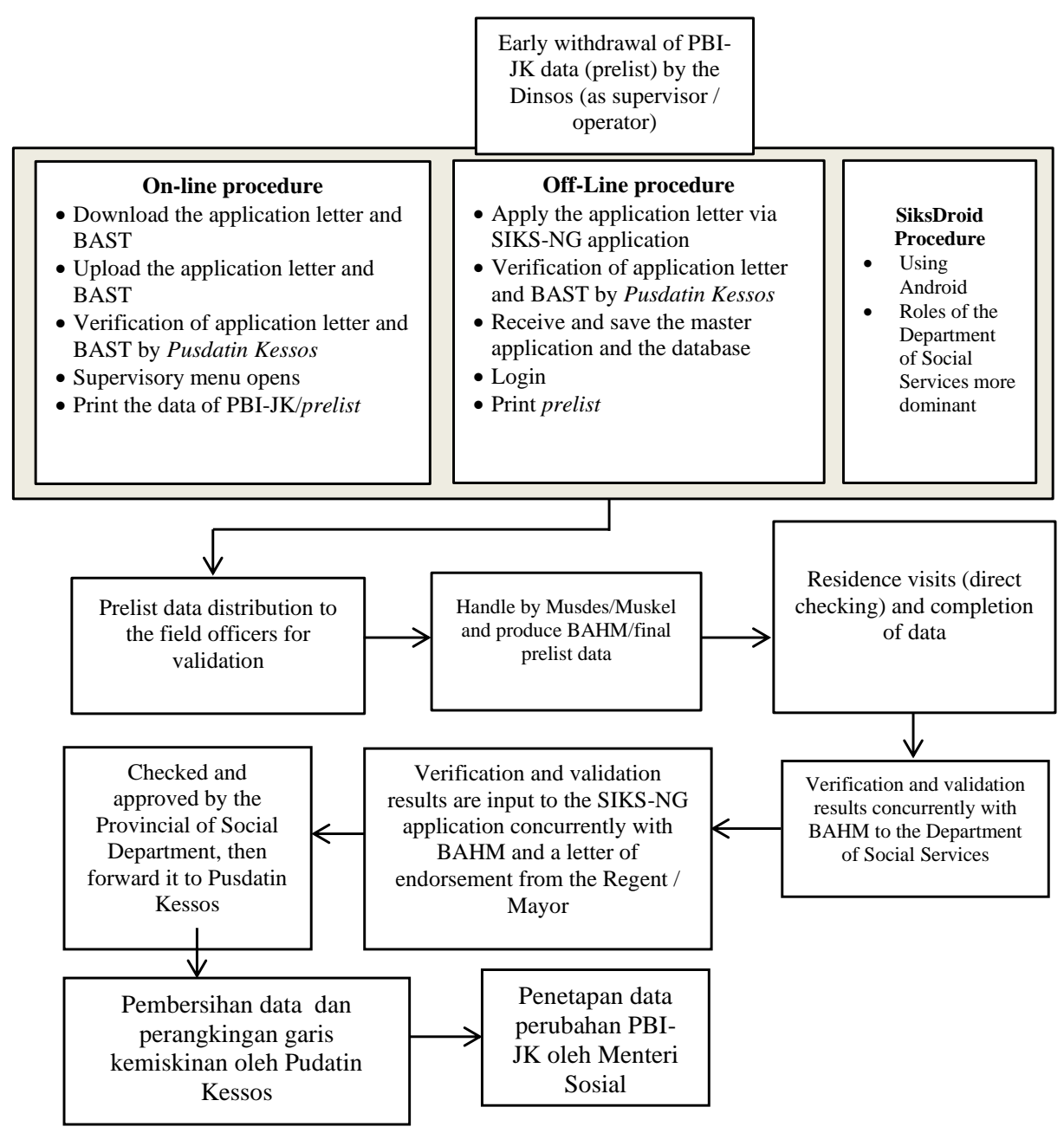

Source: Reformulated from Permensos Number 5 of 2016, and also from the result of interview with the Head of Data Center for Pusdatin Kessos on February 26, 2020.

5. Implementation of Verification and Validation of PBI-JK Data

In accordance with The Government Regulation Number 76 year 2015, changes in PBIJK data can be made including deletion, addition and replacement. However, the changing process can only be done by Pusdatin as the Ministry of Social work unit who responsible for processing, storing and providing PBI-JK data. In carrying out their duties, Pusdatin is assisted by the Department of Social Services (Next will be written with Dinsos) as an operational verification and validation officer in the field, and the results are reported in several stages to the Ministry of Social Affairs through Pusdatin

In its implementation, verification and validation of PBI-JK data begin with the prelist data retrieval which can be done online, offline or 
cyclic through the SIKS-NG application. These techniques in purpose for branches in other areas easier to derive the prelist data. But before retrieving the data, Dinsos must first submits an application letter to Pusdatin to get approval. Later Dinsos will get an ID and password to access the SIKS-NG application then able to download the BAST (handover letter), and re-upload the BAST into the system. If the request approved, the operator from Dinsos prints the prelist data in accordance with their area of origin and hand over it to the field officer for further verification and validation.

In accordance with Permensos Number 5 year 2016, the operational domain of verification and validation of PBI-JK data is the Ministry of Social Affairs assisted by District Social Welfare Worker (TKSK) and Potential Social Welfare Resources (PSKS). Specifically in Muba Regency and Palembang City, verification and validation are carried out by the third party namely PT Indonesian Classification Bureau (BKI) in collaboration with the Ministry of Social Affairs. This collaboration aims to help regions that have not yet carried out verification and validation. With the involvement of third party, the Social Affairs Office is only charged with providing prelist data, handing it over to BKI field officers, making assignment letter for field officers, and monitoring verification and validation in the field as well as evaluation.

The absence of Social Affairs in the field verification and validation processes was stated by the Head division of Individual Empowerment and Social Affairs of District Muba and this also applied in the City of Palembang according to the Head division of Social Welfare at the Social Affairs Office Palembang City. As mentioned earlier that the aim of this collaboration is to help regions who have limited resources both financial and human resources to carry out verification and validation, especially in urban areas (smaller region administration). Regarding this limitation, it was announced by the Head department of Protection and Social Security Palembang City who stated that the human resources in Palembang were not ready to carry out their duties related to the budget constraint. Similar problem also occurs in Muba Regency. 


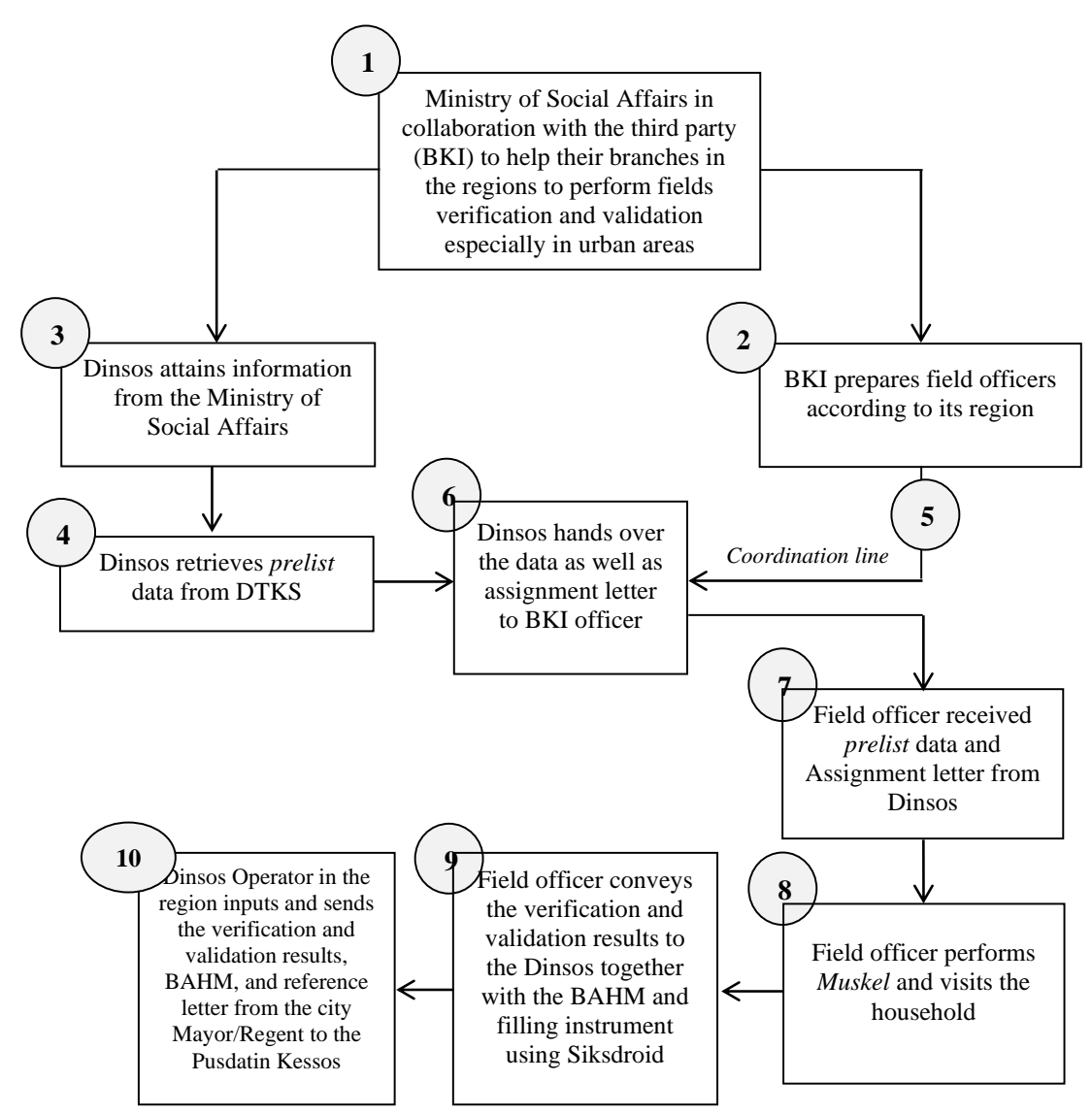

Figure 3. Implementation of Verification and Validation of PBI-JK Data

Source: Interview result with the Head Division of Data and Information Services Pusdatin Kessos

Regarding the execution of verification and validation, it is only implemented in urban areas. This was confirmed by the Head of Peldatin Pusdatin which states that the third party only carry out verification and validation in the Subdistrict (kelurahan), meanwhile in rural areas (village) the execution will be carried out by the Social Department using the Village Fund Assistant which extracted from the state budget. This case occurred in Muba Regency, where verification and validation was only carried out in 13 Subdistricts, while other 227 villages have not been done yet stated by the Head division of Muba PPK. For Palembang City, according to the Head Division of Social Welfare Palembang City, every subdistricts have been verified and validated, this was because all administrative areas (subdistrict level) located in the urban area.

6. The Improvement of PBI-JK Data Verification and Validation Implementation
The implementation of validation and verification PBI-JK data process above can be shown that the producing process, saving and data servicing was done centralists (centralistic) in Pusdatin Social Ministry. It was because the processed data, stored and used can be accounted for, even the quality of the data and the usage. In other words, this centralistic system may obstruct the process of information speed and data region needed. Moreover, the Pusdatin officers' task did not only produce and service the PBI-JK's data but they also provide and produce other social prosperity data. Such; The Government of Social Welfare Services Data (PPKS), Beneficiaries of Social Assistance and Empowerment, and Potential and Sources of Social Welfare.

Moreover, by one gate data system services (centralized in DTKS) that makes Pusdatin Social Ministry have to service all the stakeholders (stakeholders) social welfare data, such as; state 
ministries/institutions, regional governments, and the general public. This condition made Pusdatin Social Ministry as a busy and crowded place. It also recognized by the head section of Peldatin Pusdatin that every day Pusdatin Kessos have to serve both from the center and the regional visitors.

If we see from the user side, especially the local government, this centralized system creates inefficiency, both in cost and time because the local government must come to the Pusdatin Office in Jakarta if we want to ask or consult about their regional data and information. Even though Pusdatin provides online services, in some cases, local governments usually come to the Pusdatin Kessos office to find out their requests immediately.

Therefore, to reduce the prodigality, and to fasten the data service and information, and empowering human resources at the local level; the limited distribution of authority (limited decentralization) provides the data services to regional governments and the regional public that can be a viable alternative. It was done because Pusdatin Kessos focuses on processing, storing, and serving data at the central level.

Limited decentralization can be applied by making data services information at the province level (Pusdatin Kessos Provinsi), specifically providing services to local governments and other stakeholders in the regions. Pusdatin Kessos Province is structurally controlled by the central Pusdatin directly.

This limited decentralization aligned with the spirit of regional autonomy (decentralization) and good governance (good governance); involving the region (participatory) in implementing government policies. This involvement is expected can improve the quality of the public service system. Or in Sarundajang (2002) Rondinelli, Nellis, and Cheema (1983) can improve government performance in providing services to the public.

Regional involvement (Social Ministry) is also to be done in applying validation and verification; which the previous validation and verification were carried out by a third mediator, now is the time for the government to empower the internal verification and validation personnel, in this case, the Social Ministry and the devices below. The involvement of the Social Ministry has been regulated in Permensos Number 5 in 2016, but due to the budget and human resource constraints in the region (unable to carry out verification and validation), that made the Ministry of Social Affairs take steps to cooperate with the third mediator. This step was taken to implement verification and validation can still be carried out, especially in urban areas (village office).

To prepare regions involved directly in the implementation of verification and validation, the government needs to prepare adequate budget allocations, and prepare human resources to become field implementers. This budget allocation is intended for operational costs of verification and validation in the field, socialization costs, technical guidance for field staff, honorarium for monitoring and supervision, administration, and so forth. Coupled with the number of rural/urban villages reaching 83,931, making the adequacy of the budget becomes the main thing in carrying out the verification and validation of PBI-JK data.

To accomplish the verification and validation budget for all villages and local villages throughout Indonesia, the central government can work with local governments or join with other ministries/state institutions that have budgets related to villages/local villages. For example, working with local governments through the joint financing of verification and validation in their regions, and cooperate with other ministries/state institutions through the synergy of the updating program. According to the Head of Peldatin Pusdatin, the Ministry of Social Affairs is planning to work closely with the Ministry of Villages to carry out the updating social programs in villages throughout Indonesia.

While for preparing the human resources, The Social Ministry opening the recruitment (selection) for the prospective field workers that based on their respective regions, and increase their 
capacity (capacity building), so that they are expected to be skilled and competent field workers. This was stated by Harrel, Ghosh, Bowden (2004) stated that "the person or group doing the modeling should be well trained and proficient in the use of one or more simulation packages"

Also in involving the region's implementation of verification and validation, another more important factor is the involvement of the community in monitoring the verification and validation of the field (village/village meetings and household visits). With the supervision of the community, it is expected to reduce the irregularities and inaccurate program targets. Therefore the transparency of information (transparency) and public accountability (accountability) becomes important to be conveyed, besides as a form of commitment toward the openness information system (openness), also to get the input, feedback (feedback) from the public to improve the quality of social assistance for the poor family, especially the provision of health insurance social assistance.

\section{Conclusion}

The provision of health insurance assistance is basically aimed at ensuring that poor citizens are protected in terms of health. To ensure the assistance is right on target (selection system), it is necessary to update, verification and validation of the PBI-JK data. In its implementation, the prelist mechanism can only be carried out by the Department of Social Services through Pusdatin Kessos as the administrator of the DTKS (centralized system), while field verification and validation both in Muba Regency and Palembang City delegated to the third party. Currently, verification and validation actions are only carried out in urban areas (Subdistrict).

Departing from the description above, in order to improve the organization of verification and validation PBI-JK data, the Ministry of Social Affairs needs to openly provide mechanism and implementation of verification and validation to the public, restructure the Pusdatin Kessos organization by create additional work units at the provincial level specifically to provide data services in the regions, involve the Department of Social Services (Dinsos) in the verification and validation implementations as stipulated in Permensos Number 5 Year 2016 and also engage the community to monitor the verification and validation in the field.

\section{REFERENCES}

[1] Agere, Sam. (2000). Promoting good governance principles, practices and perspective. London: Commonwealth Secretariat.

[2] Ahmad, Reza.(2008). Governance, social accountability and the civil socienty. Journal of Administration and Governance, vol 3, no 1 .

[3] Bjuremalm, Helena,. Gibaja, Alberto, Fernandez,. \& Molleda, Jorge Vallandares. (2014). A practical guide to identify improvements through assesment. Sweden: International IDEA.

[4] Blakemore, K., \& Griggs, Edwin. (2007). Social policy: an introduction (3rd ed). New York: McGrawHill.

[5] Blau, Joe,. \& Abramovitz, Mimi. (2003). The dynamic of social welfare policy. New York: Oxford University Press.

[6] Creswell, J.W. (2016). Metodologi penelitian sosial: pendekatan kualitatif dan kuantitatif (7th ed). Jakarta: Indeks.

[7] Daly, Mary. (2003). Governance \& social policy. Journal of Social Policy, 32:113 128.

[8] DiNitto, Diana. M. (2003). Social welfare: public and public policy (5th edition). Boston: Pearson Education.

[9] Direktorat Perlindungan dan Kesejahteraan Masyarakat Kementerian Perencanaan Pembangunan Nasional/Bappenas. (2014). 
Perlindungan sosial di Indonesia: tantangan dan arah ke depan. Jakarta: Tim penulis.

[10] Doeveren, Van, Veerle. (2011). Rethinking good governance: identifying common principles. Public Integrity, 13:4, 301-318

[11] Gilbert, Neil,. \& Terrell, Paul. (2013). Social welfare policy (8th edition). USA: Pearson.

[12] Gisselquist, M, Rachel. (2012). Good governance as a concept, and why this matters for development. UNU-Wider: Working paper No 30/30

[13] Hepat, D, Rian.,dan Rachman Ellys. (2018). Faktor-faktor penghambat pendataan penerima bantuan iuran (PBI) BPJS Kesehatan di Kelurahan Heledululaa Utara Kecamatan Kota Timur Kota Gorontalo. Jurnal Manajemen Sumber Daya Manusia, Admnistrasi dan Pelayanan Publik, STIA Bina Taruna Gorontalo, Volume V nomor 2

[14] Johnston, Michael. (2009). Good governance rule of law, transparency \& accountability <etico.iiep.unesco.org>, dilihat tanggal 5 Maret 2020, pukul 12.58 wib

[15] Muhtar. (2015). Implementasi kebijakan perlindungan sosial jaminan kesehatan bagi penduduk miskin. Jurnal Penelitian Kesejahteraan Sosial, vol 14, nomor 4, Desember 2015, 397 - 410

[16] Maulana, Akbar. (2019). Implementasi kebijakan verifikasi dan validasi data PBIJKN: Ssudi di Kecamatan Ambulu, Kabupaten Jember. Tesis: Magister Ilmu Adminstrasi, FISIP, Universitas Jember.

[17] Pedoman Jaminan Kesehatan Masyarakat Musi Banyuasin. (2019). Dinas Kesehatan Kabupaten Musi Banyuasin

[18] Rondinelli, Dennis, A,. Nellis, John, R,. \& Cheema, R, Gabbir. Dezentralization in developing countries; A review of recent experience. Washington:
The International Bank for Reconstruction and Development/World Bank

[19] Rubin, Allen., \& Babbie,E.R. (2008). Research methods for social work (6th edition). California: Thomson Brooks/Cole.

[20] Sarundanjang, S,H. (2002). Arus balik kekuasan pusat ke daerah. Jakarta: Pustaka Sinar Harapan

[21] Sparow, Robert., Suryahadi., Asep, Widyanti., \& Wenefrida. (2013). Social health insurance for the poor: targeting and impact of Indonesia's askeskin programme. Social Science \& Medicine Journal, 96, 264 $-271$.

[22] Sparow, Robert., Suryahadi., Asep, Widyanti.,\& Wenefrida. (2013). Social health insurance for the poor: targeting and impact of Indonesia's askeskin programme. Social Science \& Medicine Journal, 96, 264 $-271$.

[23] Suharto, Edi. (2006). Negara kesejahteraan dan reinventing depsos. Paper disampaikan dalam Seminar Negara Kesejahteraan (Welfare State), Jogjakarta: Universitas Gajah Mada.

[24] Suharto, Edi. (2007). Kebijakan sosial sebagai kebijakan publik; peran pembangunan kesejahteraan sosial dan pekerjaan sosial dalam mewujudkan negara kesejahteraan (welfare) di Indonesia. Bandung: Alfabeta

\section{Peraturan dan Perundang-Undangan}

[25] UU Nomor 40 Tahun 2004 tentang Sistem Jaminan Sosial Nasional

[26] UU Nomor 32 Tahun 2004 tentang Pemerintah Daerah

[27] UU Nomor 25 Tahun 2009 tentang Pelayanan Publik

[28] UU Nomor 11 Tahun 2009 tentang Kesejahteraan Sosial

[29] UU Nomor 24 Tahun 2011 tentang Badan Penyelenggara Jaminan Sosial 
[30] UU Nomor 13 Tahun 2011 tentang penanganan Fakir Miskin

[31] UU Nomor 6 Tahun 2014 tentang Desa

[32] PP Nomor 101 Tahun 2012 tentang Penerima Bantuan Iuran

[33] PP Nomor 60 Tahun 2014 tentang Dana Desa yang Bersumber APBN

[34] PP Nomor 76 Tahun 2015 tentang Perubahan atas PP Nomor 101 Tahun 2012 tentang Penerima Bantuan Iuran Jaminan Kesehatan

[35] PP Nomor 82 Tahun 2018 tentang Jaminan Kesehatan

[36] Permensos Nomor 5 Tahun 2016 tentang Pelaksanaan Peraturan pemerintah Nomor 101 Tahun 2012 tentang Penerima Bantuan Iuran Jaminan Kesehatan

[37] Permensos Nomor 28 Tahun 2017 tentang Pedoman Umum Verifikasi dan Validasi Data Terpadu Penanganan Fakir Miskin dan Orang Tidak Mampu

[38] Permensos Nomor 28 Tahun 2018 tentang Tenaga Kesejahteraan Sosial Kecamatan

[39] Permensos Nomor 5 Tahun 2019 tentang Pengelolaan Data terpadu Kesejahteraan Sosial

[40] Permendagri Nomor 134 Tahun 2017 tentang Perubahan Atas Peraturan Menteri dalam Negeri Nomor 33 Tahun 2017 tentang Pedoman Penyusunan Anggaran Pendapatan dan Belanja Daerah Tahun Anggaran 2018

[41] Kepmensos Nomor 146/HUK/2013 tentang Penetapan Kriteria dan Pendataan Fakir Miskin dan Orang Tidak Mampu

[42] Kepmensos Nomor 147/HUK/2013 tentang Penetapan Penerima Bantuan Iuran

[43] Kepmensos Nomor 42/HUK/2015 tentang Perubahan Keputusan nomor 25/HUK/2015 tentang Penetapan Penerima Bantuan Iuran Jaminan Kesehatan Tahun 2015

[44] Kepmensos Nomor 25/HUK/2015 tentang Penetapan Penerima Bantuan Iuran Jaminan Kesehatan Tahun 2015
[45] Kepmensos Nomor 58/HUK/2015 tentang Penetapan Penerima Bantuan Iuran Jaminan Kesehatan Tambahan Tahap Kedua Tahun 2015

[46] Kepmensos Nomor 93/HUK/2015 tentang Penetapan Penerima Bantuan Iuran Jaminan Kesehatan Hasil Verifikasi dan Validasi di 23 (Dua Puluh Tiga) Kabupaten/Kota

[47] Kepmensos Nomor 170/HUK/2015 tentang Penetapan Penerima Bantuan Iuran Jaminan Kesehatan Tahun 2016

[48] Kepmensos Nomor 23/HUK/ tentang Penetapan Penonaktifan Peserta Penerima Bantuan Iuran Jaminan Kesehatan Tahun 2018

[49] Permensos Nomor 01/HUK/2019 tentang Penetapan Penerima Bantuan Iuran Jaminan Kesehatan Tahun 2019

[50] Inpres Nomor 8 Tahun 2017 tentang Optimalisasi Pelaksanaan Program Jaminan Kesehatan Nasional.

[51] Perda Provinsi Sumatera Selatan Nomor 2 Tahun 2009 tentang Penyelenggaraan Jaminan Sosial Kesehatan Sumatera Selatan Semesta (Jamsoskes Sumsel Semesta).

[52] Peraturan DJSN Nomor 01 Tahun 2016 tentang Kebijakan Umum Integrasi Program Jaminan Kesehatan Daerah ke Dalam Program Jaminan Kesehatan Nasional

[53] Buku Panduan SIKS-NG. (2018) Pusdatin Kessos; Kementerian Sosial Republik Indonesia.

[54] Buku Panduan Supervisor Penerima Bantuan Iuran Jaminan Kesehatan (PBIJK). (n.d) Pusdatin Kessos; Kementerian Sosial Republik Indonesia.

[55] SiksDroid (n.d) Pusdatin Kessos; Kementerian Sosial Republik Indonesia

[56] Petunjuk Teknis Penggunaan Aplikasi SIKS-NG Versi Online. (2019) Pusdatin Kessos; Kementerian Sosial Republik Indonesia. 